\title{
ECOLOGICAL STUDIES ON THE POLYMORPHIC LADYBIRD ADALIA BIPUNCTATA IN THE NETHERLANDS. I. POPULATION BIOLOGY AND GEOGRAPHICAL VARIATION OF MELANISM
}

\author{
BY PAUL M. BRAKEFIELD* \\ Department of Population and Evolutionary Biology, University of Utrecht, Padualaan 8 , \\ Utrecht, The Netherlands
}

\section{SUMMARY}

(1) Samples of the polymorphic two-spot ladybird Adalia bipunctata were collected at seventy-five sites in the Netherlands and northern Belgium. Most sites were on four transects up to $120 \mathrm{~km}$ long. Sequential sampling at thirteen sites was used to examine basic population biology.

(2) Shrubs, especially Rosa rugosa and Crataegus spp., provide feeding and mating habitats in late April and May following hibernation. Some oviposition may also occur. Adults disperse from mid-May to trees, particularly Tilia spp., which are the principal habitats for egg laying in many populations. At some sites in some years a substantial second, late summer or autumn generation occurs. Reproduction probably tends to occur earlier inland than on the coast. There are differences in timing between years.

(3) Frequencies of melanics are $1-15 \%$ in the north-west and $>50 \%$ inland in the south-east. Steep clines occur over part of the transition between these regions, possibly due to a partial barrier to gene flow. Frequency changes were probably more marked for the quadrimaculata than the sexpustulata melanic morph.

(4) Among the correlations between melanic frequency and climatic variables are negative ones with an index of oceanity, relative humidity and length of sunshine. The last is consistent with thermal melanism. The interpretation of the relationships with environmental variables is discussed.

\section{INTRODUCTION}

The two-spot ladybird beetle Adalia bipunctata (L.) is polymorphic for several non-melanic and melanic forms. These are controlled by a number of alleles at a single gene locus with the melanic morphs being dominant to non-melanics (Lus 1928, 1932). A number of studies have examined geographical variation in morph frequency. Several workers have carried out regression analysis of the relationships between climatic variables and the frequency of melanics (Lees, Creed \& Duckett 1973; Creed 1975; Muggleton, Lonsdale \& Benham 1975; Scali \& Creed 1975; Bengtson \& Hagen 1977). These studies have led to the development of several theories to account for the variation (see review by Muggleton 1978).

This paper describes the results of a survey of morph frequency in the Netherlands and

\footnotetext{
* Present address: Department of Biological Sciences, University of Exeter, Perry Road, Exeter EX4 4QG.
} 
northern Belgium. The relationships between the frequency data and some climatic variables are examined. The work on polymorphism in A. bipunctata has been conducted without an extensive ecological understanding of the species. This study therefore examines the basic population biology in the Netherlands. The observations were made in conjunction with a comparison of the adult movement and reproductive activity of melanics and non-melanics (Brakefield 1984a,b).

\section{METHODS}

\section{Study area}

In the Netherlands $A$. bipunctata is an abundant species found in most urban areas. Figure 1 shows the distribution of study sites. Some were scattered through the Netherlands and northern Belgium. Most sites were, however, located along four transects in central and southern Holland: A and B running approximately eastwards from the coast and $\mathrm{C}$ and $\mathrm{D}$, bisecting these two from north to south. The transects were 90 or $120 \mathrm{~km}$ long.

\section{The samples}

Samples of $A$. bipunctata were collected from each site between 1978 and 1982 . In the Netherlands only three morphs of $A$. bipunctata are abundant; all others together comprising less than $1 \%$ of a population. The three morphs are the non-melanic red typica and the melanic quadrimaculata and sexpustulata with four and six red spots respectively.

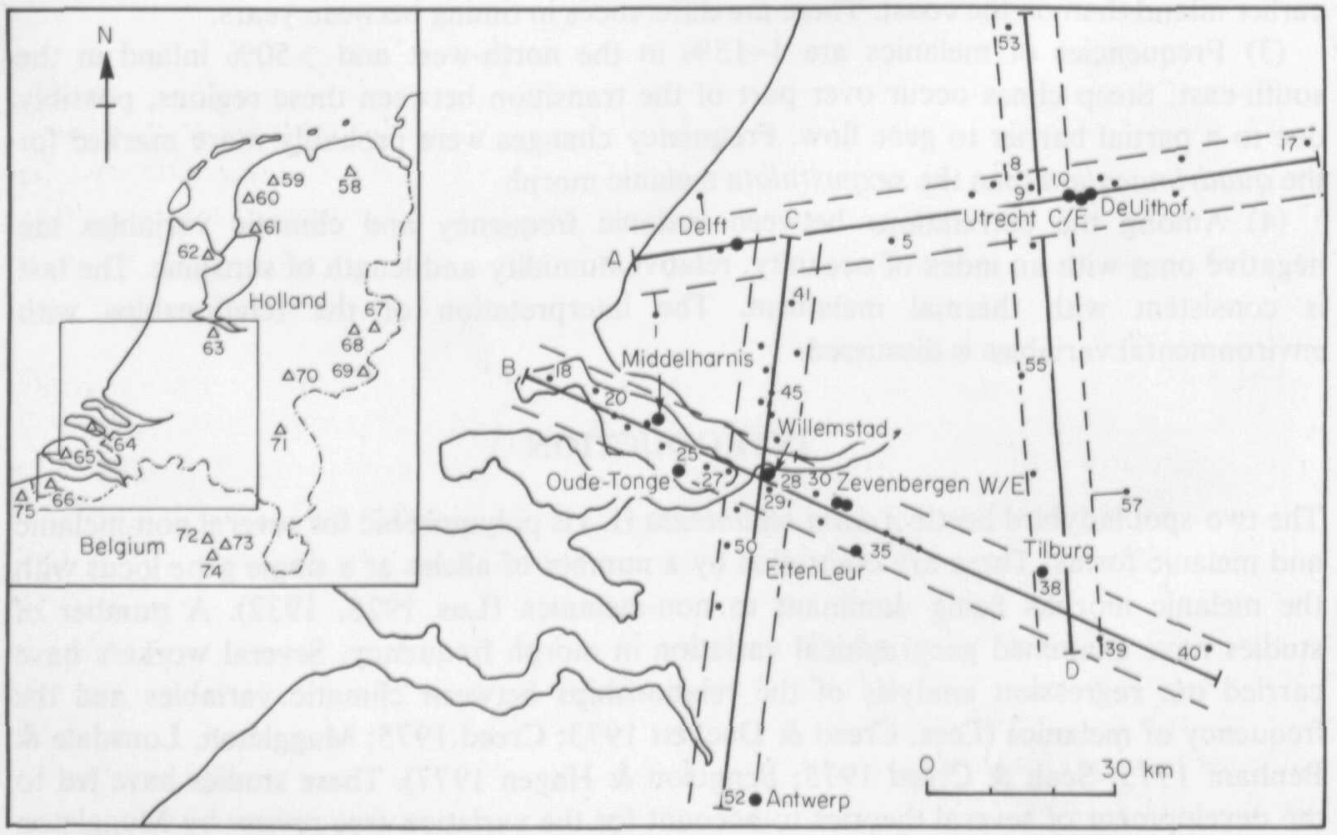

Fig. 1. Map of the study sites: $(\Delta)$, general sites; $(\cdot)$, sites on four transects A-D; (-- ), $\pm 5 \mathrm{~km}$ limits for transect width (transect sites outside these limits are connected by lines). Names refer to larger circles $(\bullet)$ and indicate sites from which series of samples of pupae were obtained. Sites are numbered individually or in sequence in intervals of five. All sites names are given in Appendix 1. 
Thirteen sites from the transects were selected for further study in 1980 and 1981 (Fig. 1). Sequential sampling of adults and of prepupae and pupae was carried out at each site, usually in a number of different habitats. Samples of adults from shrub habitats where a high sampling intensity was possible represent counts rather than collections. During sampling of a habitat the same area was searched systematically and in a manner that was consistent from one occasion to another. Adults emerging from pupae in the laboratory were scored following complete development of elytral phenotype. Tests of random sampling of pupae within a habitat with respect to morph class were made. Eleven comparisons of morph frequency in subsamples collected from: (i) different areas of a habitat; (ii) trunk and leaves of trees; (iii) upper and lower leaf surfaces or (iv) leaves with single or grouped pupae, showed no differences $(P>0.25$ for each test).

Laboratory dissection showed that sex differentiation was unreliable in the field. The sexual dimorphism in size was quantified for some populations by weight analysis of the members of mating pairs following drying to constant weight at $60^{\circ} \mathrm{C}$. Some estimates of sex ratio in successive samples from one site were obtained by comparison of the frequency distribution of weight in non-mating adults with that in the mating males and females. For each weight class the proportion of each sex in the non-mating beetles is estimated as equivalent to the proportion in the mating sample. Dissection of one of these samples of non-mating beetles $(n=140)$ showed no difference between the actual and estimated proportions $(G=0.97$, d.f. $=1, P>0.1)$. The weight data are also analysed to examine temporal changes in reproductive condition.

\section{RESULTS}

\section{Population biology}

\section{Hibernation}

Adults hibernate from October or early November to April. Hibernation occurs mainly on trees at rural sites but in buildings in urban areas. Behaviour during hibernation will be described in detail elsewhere. Migration both to and from hibernacula continues over several weeks.

\section{First generation}

The data for number of pupae collected on separate dates in different habitats at a site are used to examine the pattern of pupation. In 1980 the pattern at several sites indicates a parallel sequence of breeding habitats on plants supporting the aphid prey of $A$. bipunctata (Fig. 2a). Early recruitment in May and June occurred on shrubs, particularly hawthorn Crataegus spp. and the ornamental and extensively planted Rosa rugosa. Later recruitment in June and July was on trees, principally lime Tilia spp. The same pattern is evident in the post-hibernation adult populations (see Brakefield 1984a, Fig. 5). Early adults are found on shrubs where mating occurs at high frequencies of up to $44 \%$. Oviposition and subsequent recruitment on the shrubs may or may not occur. Dispersal to Tilia begins following budburst in mid- or late May. Figure 2b shows that in 1981 pupation on Tilia was earlier and that higher densities of pupae occurred. At most sites there was little evidence of earlier recruitment on shrubs although such habitats did provide adult mating sites.

Male $A$. bipunctata are smaller than females (Table 1). There are no differences in dry weight between morphs or between populations. The weight analysis of samples of post-hibernation adults from Tilburg yields evidence of an overall excess of males on Rosa 
(a)
4 Delft
10 Utrecht $\mathrm{C}$.

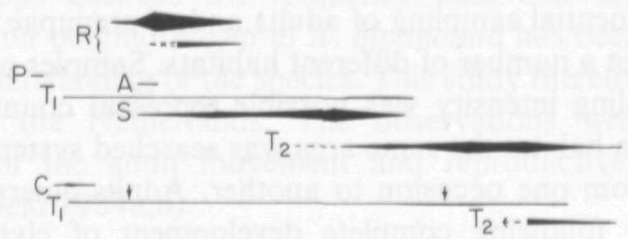

23 Middelharnis

25 Oude-Tonge

28 Willemstad

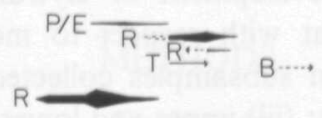

32 Zevenbergen $\mathrm{W}$.

33 Zevenbergen $E$.

38 Tilburg

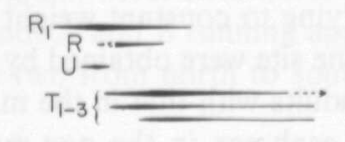

52 Antwerp

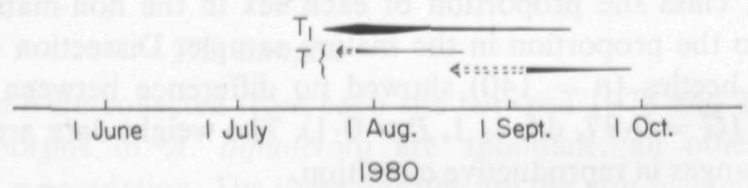

(b)

4 Delft

10 Utrecht C.

II Utrecht $E$.

12 Uithof

25 Oude -Tonge

28 Willemstad

32 Zevenbergen $W$.

33 Zevenbergen $E$.

34 Etten Leur
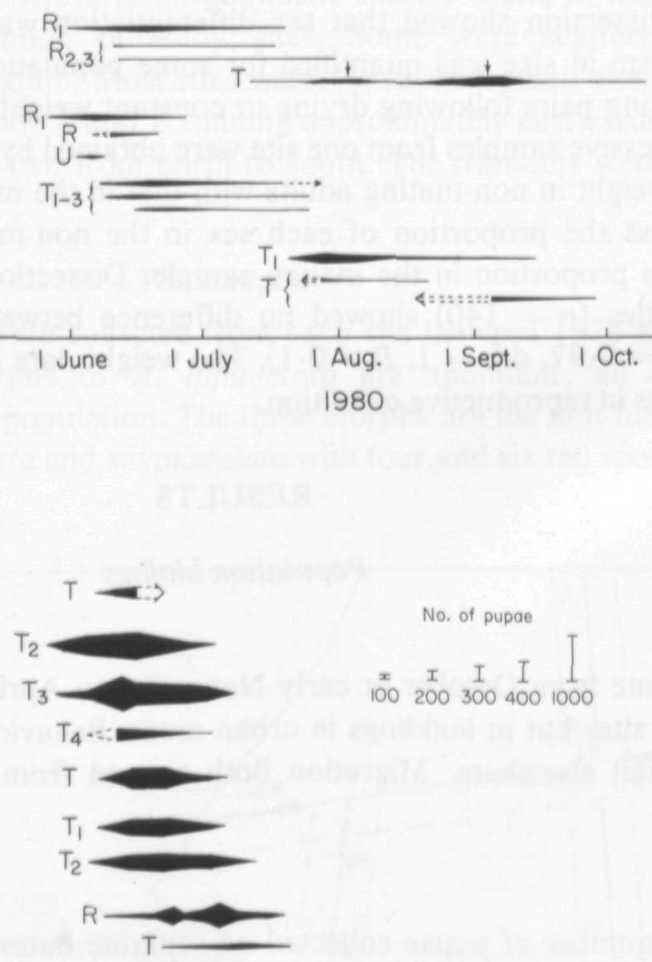

980

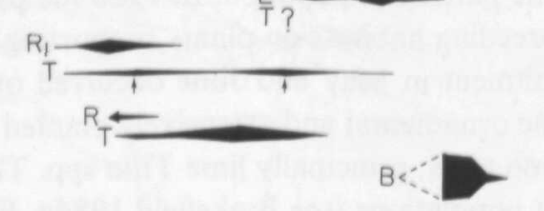

38 Tilburg

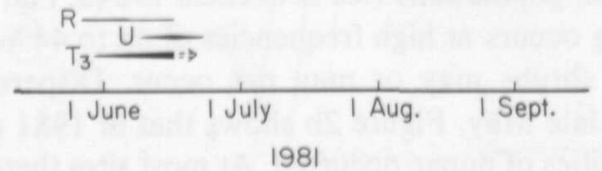

Fig. 2. Temporal changes in the size of sequential samples of pupae of Adalia bipunctata at the sites indicated. Plant habitats: $\mathrm{A}=$ Acer campestre $\mathrm{L}$., $\mathrm{B}=$ Betula spp.; $\mathrm{C}=$ Crataegus spp.; $\mathrm{E}=$ Sambucus nigra $\mathrm{L}$.; $\mathrm{P}=$ Prunus spp.; $\mathrm{R}=$ Rosa rugosa Thunb., $\mathrm{S}=$ Salix spp.; $\mathrm{T}=$ Tilia spp.; U = Urtica dioica L. (not shown: Euonymus europaeus L., Acer pseudoplatanus L.). Arrows indicate two peaks in numbers. 
TABLE 1. Dry weight (mean $\pm 95 \%$ C.L.) of the non-melanic typica (typ) and melanic quadrimaculata $(\mathrm{m} 4)$ and sexpustulata $(\mathrm{m} 6)$ morphs of male and female Adalia bipunctata collected in copula in 1980. Samples are those of posthibernation adults from the sites indicated

\begin{tabular}{|c|c|c|c|c|c|c|c|c|c|c|}
\hline \multirow[b]{2}{*}{ no. } & \multirow{2}{*}{$\begin{array}{l}\text { Site } \\
\text { name }\end{array}$} & \multirow{2}{*}{$\begin{array}{c}n \\
\text { pairs }\end{array}$} & \multicolumn{4}{|c|}{ Males } & \multicolumn{4}{|c|}{ Females } \\
\hline & & & typ & $\mathrm{m} 4$ & $\mathrm{~m} 6$ & all & typ & $\mathrm{m} 4$ & $\mathrm{~m} 6$ & all \\
\hline 38 & Tilburg & 222 & 4. 209 & $4 \cdot 129$ & 4. 290 & $4 \cdot 185$ & 6.042 & 5.872 & 5.963 & 5.954 \\
\hline 31 & Oudenbosch & 180 & $\begin{array}{r} \pm 0.130 \\
4.212\end{array}$ & \pm 0.125 & \pm 0.279 & \pm 0.087 & \pm 0.218 & \pm 0.222 & \pm 0.433 & \pm 0.148 \\
\hline & & & $\begin{array}{r}4.212 \\
+0.151\end{array}$ & $\begin{array}{r}4.188 \\
+0.150\end{array}$ & $\begin{array}{r}4.002 \\
+0.277\end{array}$ & $\begin{array}{r}4.165 \\
+0.101\end{array}$ & $\begin{array}{r}5.891 \\
+0.229\end{array}$ & $\begin{array}{r}6.156 \\
+0.241\end{array}$ & $\begin{array}{r}6.147 \\
+0.600\end{array}$ & $\begin{array}{l}6.042 \\
0.163\end{array}$ \\
\hline 12 & De Uithof & 119 & $\begin{array}{r}4.129 \\
+0.120\end{array}$ & $\begin{array}{r}4.337 \\
+0.246\end{array}$ & $\begin{array}{r}4.486 \\
+0.320\end{array}$ & $\begin{array}{r}4.180 \\
+0.107\end{array}$ & $\begin{array}{r}5.846 \\
+0.238\end{array}$ & $\begin{array}{r}5.714 \\
+0.484\end{array}$ & $\begin{array}{r}6.318 \\
+0.633\end{array}$ & $\begin{array}{l}0.163 \\
5.880 \\
0.206\end{array}$ \\
\hline
\end{tabular}

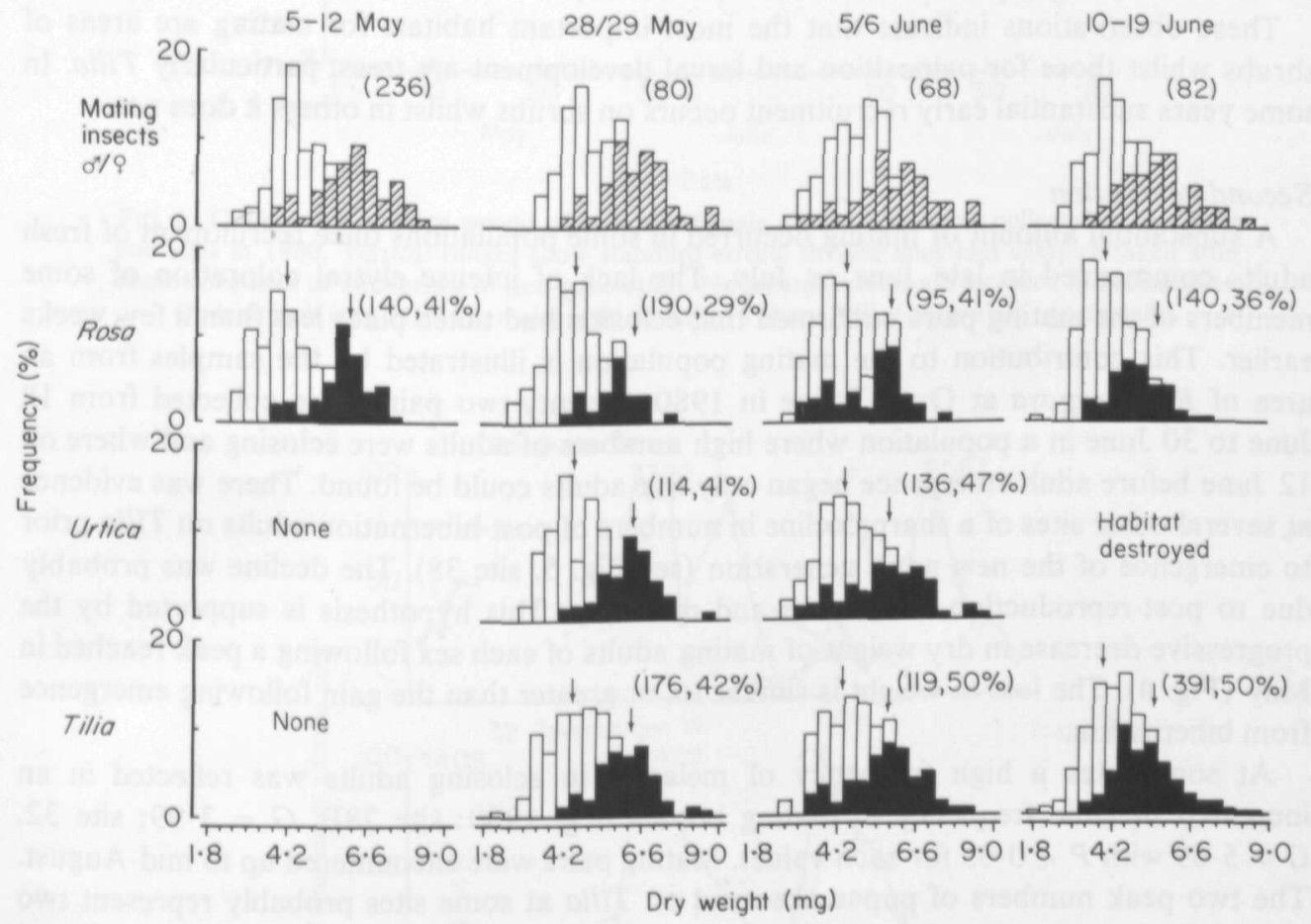

FIG. 3. Frequency of dry weight in samples of Adalia bipunctata from Tilburg (site 38) collected in consecutive periods in 1980 on different plant species. The top row shows distributions for males (unhatched) and females (hatched) in all mating pairs. The lower rows are those for total samples from each plant species (arrows show means for each sex in all mating insects). The distributions for mating insects are used to estimate the relative proportion of each sex in each total sample for the same period as indicated by shading. The sample size and estimated \% frequency of females is indicated for each sample.

and a more even sex ratio on Tilia (Fig. 3; combined non-mating samples: estimates of \% females $=36 \%$ and $48 \%$, respectively with $G=19.57, P<0.001$ ). The status of the samples from Urtica dioica is uncertain although the initial movement to Urtica is probably synchronous with that to Tilia (Fig. 3). A similar difference is indicated from a comparison of weight distribution in samples from areas of Rosa and Tilia about $100 \mathrm{~m}$ apart collected at Antwerp on 22 May 1980 soon after bud burst on the trees (mean dry weight in $\mathrm{mg}(n)$ for Rosa and Tilia respectively $=4.80$ (220) and 5.68 (139); 
Mann-Whitney $U=19163.5, P<0.001$ ). A bimodal frequency distribution on Rosa contrasted with Tilia where only a high mode was evident. Such differences suggest a stronger tendency for movement by females from the shrubs to trees than by males.

At each of the sites for which comparisons can be made there is evidence that over the mating period up to commencement of emergence from pupae, mating occurs at a substantially higher frequency on shrubs than on Tilia trees (site 12, 1980: $G=95.6$; site 38; $1980, G=16.74$ and $1981, G=41.3$ with 1 d.f. and $P<0.001$ for each value). The overall frequencies of mating beetles for these sites were $23.5 \%$ and $10.4 \%$ on shrubs and trees, respectively. In four of the five comparisons of the first sample from Tilia with that collected on the same date from nearby shrubs (see Brakefield 1984a, Table 6) mating beetles were more frequent on the $\operatorname{shrubs}^{\prime}(P<0.05)$.

These observations indicate that the most important habitats for mating are areas of shrubs whilst those for oviposition and larval development are trees, particularly Tilia. In some years substantial early recruitment occurs on shrubs whilst in others it does not.

\section{Second generation}

A substantial amount of mating occurred in some populations once recruitment of fresh adults commenced in late June or July. The lack of intense elytral coloration of some members of the mating pairs confirmed that eclosion had taken place less than a few weeks earlier. This contribution to the mating population is illustrated by the samples from an area of Rosa rugosa at Oude-Tonge in 1980. Seventy-two pairs were collected from 18 June to 30 June in a population where high numbers of adults were eclosing and where on 12 June before adult emergence began only five adults could be found. There was evidence at several other sites of a sharp decline in numbers of post-hibernation adults on Tilia prior to emergence of the new adult generation (see Fig. 5, site 38). The decline was probably due to post-reproduction senescence and mortality. This hypothesis is supported by the progressive decrease in dry weight of mating adults of each sex following a peak reached in May (Fig. 4). The loss in weight is similar to, or greater than the gain following emergence from hibernation.

At some sites a high frequency of melanics in eclosing adults was reflected in an increased melanic frequency in mating beetles (e.g. 1980: site 28E, $G=3.99$; site 32, $G=5.69$ with $P<0.05$ for each value). Mating pairs were encountered up to mid-August. The two peak numbers of pupae observed on Tilia at some sites probably represent two essentially separate generations (Fig. 2). A late second generation was sometimes found in Autumn on birch Betula spp. (Fig. 2, e.g. site 34, 1981) and on Tilia where no early breeding had occurred (e.g. site 10, 1980). The second generation is almost entirely restricted to trees. Although second generation recruitment can be substantial it is not clear how general it is in relation to differences between sites and years and to what extent a long oviposition period by a surviving cohort of the overwintered generation contributes to it.

\section{Variability between sites}

A closer examination of differences in the biology of A. bipunctata at three similar areas of Rosa rugosa is possible from Fig. 5. The areas are at sites on transect $\mathrm{C}$ at increasing distances from the coast (Oude-Tonge, 28.5 km; Zevenbergen W., $54 \mathrm{~km}$; Tilburg, $88 \mathrm{~km}$ ). Figure 5 shows that in 1981 maximum adult density on Rosa was earliest at the most inland site, Tilburg. Dispersal to Tilia also occurred earlier than nearer the coast. At Oude-Tonge nearest the coast there is evidence of two adult peaks, the second probably 


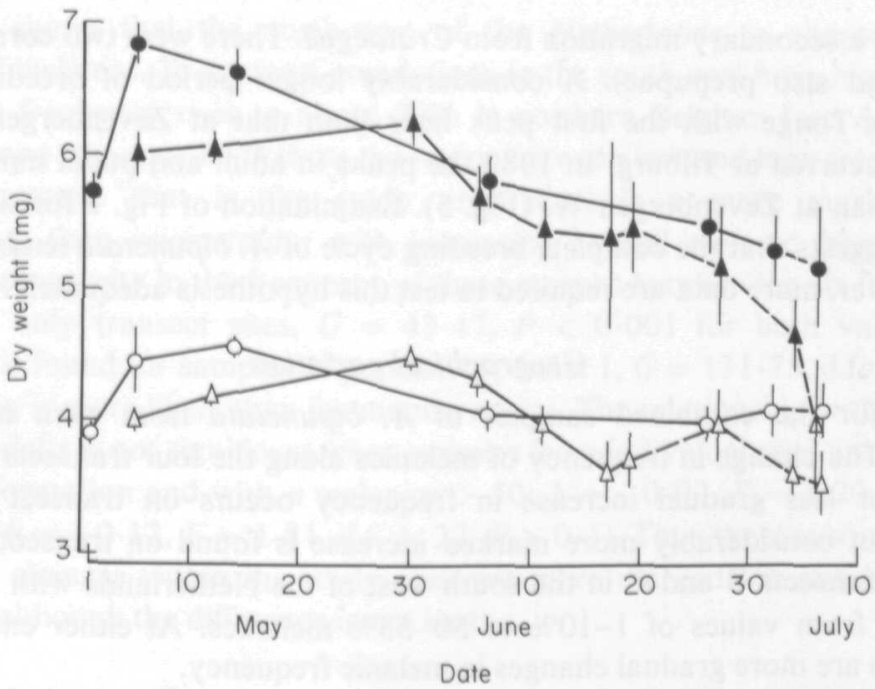

FIG. 4. Change in mean dry weight of male and female Adalia bipunctata collected in copula at two sites in 1980. Vertical ranges show standard errors. Broken lines join samples taken after commencement of emergence of new generation. No teneral insects are included in the samples.

Oudenbosch (site 31): (O), males; $(\mathbf{O})$, females. Tilburg (38): $(\triangle)$, males; $(\mathbf{\Delta})$, females.

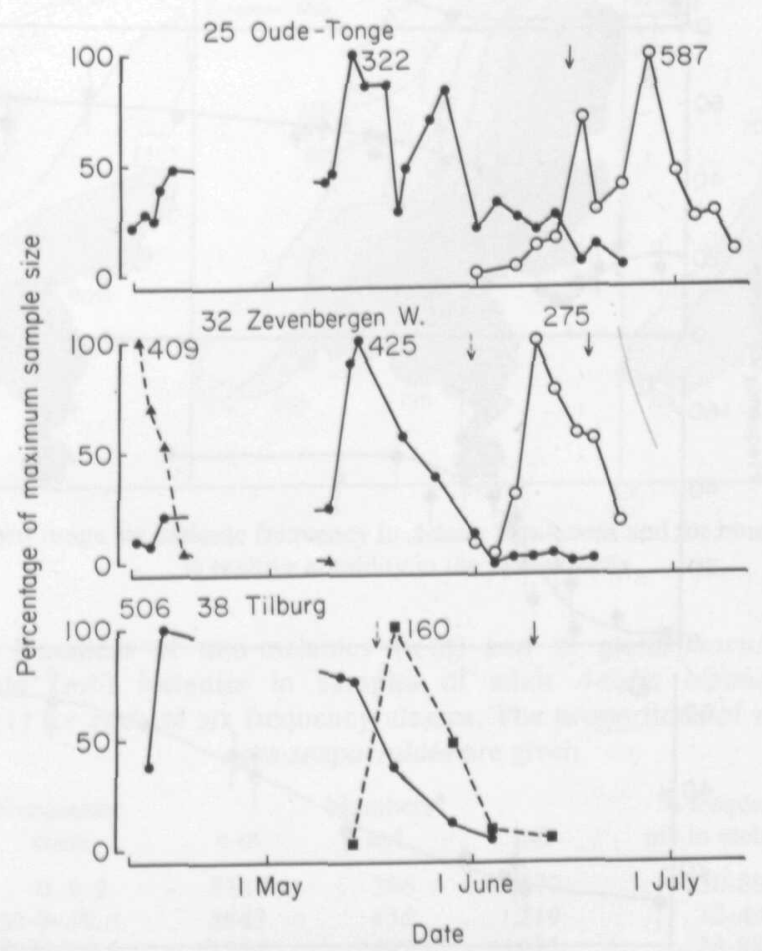

FIG. 5. Change in counts of adults (O), and samples of pupae (O) of Adalia bipunctata from single habitats of Rosa rugosa at the sites indicated in 1981. Data for adults from adjacent

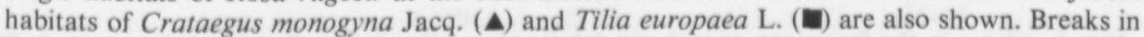
the plots indicate a period of no adult activity. Figures give maximum sample sizes. Solid arrows show peaks for pupal samples in 1980 and broken arrows those for adult counts. 
resulting from a secondary migration from Crataegus. There were two corresponding peaks for pupae (and also prepupae). A considerably longer period of breeding occurred on Ros $a$ at Oude-Tonge with the first peak later than that at Zevenbergen W. Negligible recruitment occurred at Tilburg. In 1980 the peaks in adult and pupal numbers at Tilburg were earlier than at Zevenbergen W. (Fig. 5). Examination of Fig. 2 for sites 23-38 along transect C suggests that the complete breeding cycle of $A$. bipunctata tends to occur earlier inland. However, more data are required to test this hypothesis adequately.

\section{Geographical variation}

The data for the combined samples of A. bipunctata from each site are given in Appendix 1. The change in frequency of melanics along the four transects is shown in Fig. 6. A more or less gradual increase in frequency occurs on transect A. A similarly progressive but considerably more marked increase is found on transect D. Steep clines occur along transects B and C in the south-west of the Netherlands with an increase over some $20 \mathrm{~km}$ from values of $1-10 \%$ to $50-55 \%$ melanics. At either end of these steep portions there are more gradual changes in melanic frequency.
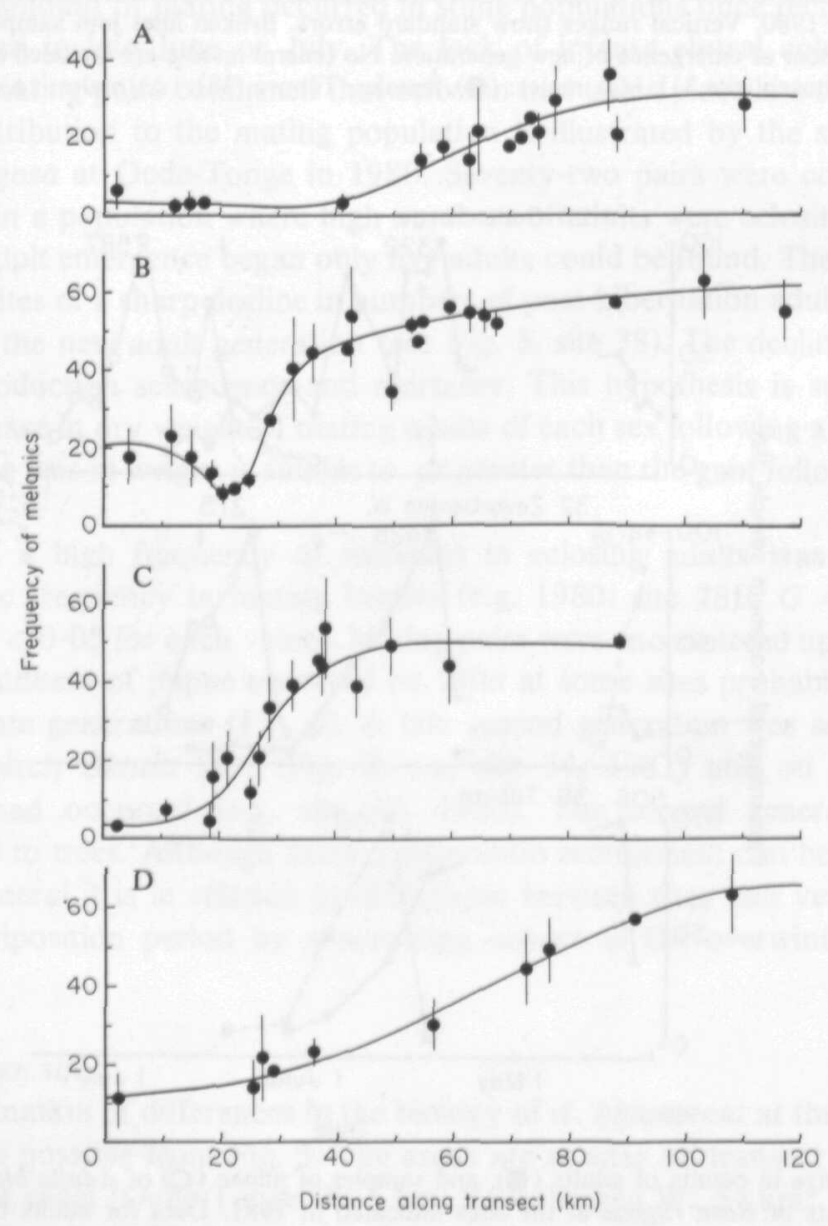

FIG. 6. Clines in the frequency of melanic Adalia bipunctata on the four study transects A-D. Vertical ranges show $95 \%$ C.L. Curves are fitted by eye. 
Figure 7a shows that the north-west of the Netherlands is characterized by low frequencies of melanics. In contrast populations in the south-east have higher than $50 \%$ of melanics. The frequency rises to about $70 \%$ in northern Belgium (see Appendix 1). The steep clines along transects B-D cross the region between low and high frequencies.

Table 2 suggests that in the study area there is a more marked increase in quadrimaculata than sexpustulata with increasing overall melanic frequency. There is significant heterogeneity in the frequency of these morphs between the six frequency classes ( $G=44.96$; only transect sites, $G=43.47, P<0.001$ for both values). A similar heterogeneity is found for samples of pupae (Appendix $1, G=131.75$, d.f. $=4, P<0.001$ ) but mis-scoring is more likely than for mature adults. The relationship with overall melanic frequency in adults is not significant when samples from individual sites are analysed (using angular transformation and with $n$ melanics $>50 ; b=-0 \cdot 09, F=1 \cdot 20$, d.f. 1,24 ; only transect sites, $b=-0.12, F=1.81$, d.f. $1,22, P>0.1)$. Thus there is some evidence that the frequency changes within the study area are more marked for quadrimaculata than sexpustulata, although the difference is not larg..

\section{Climatic correlations}

There is a negative relationship between the hours of spring sunshine and the frequency of melanics (Fig. 7a,b). The relationship tends to break down outside the months April to

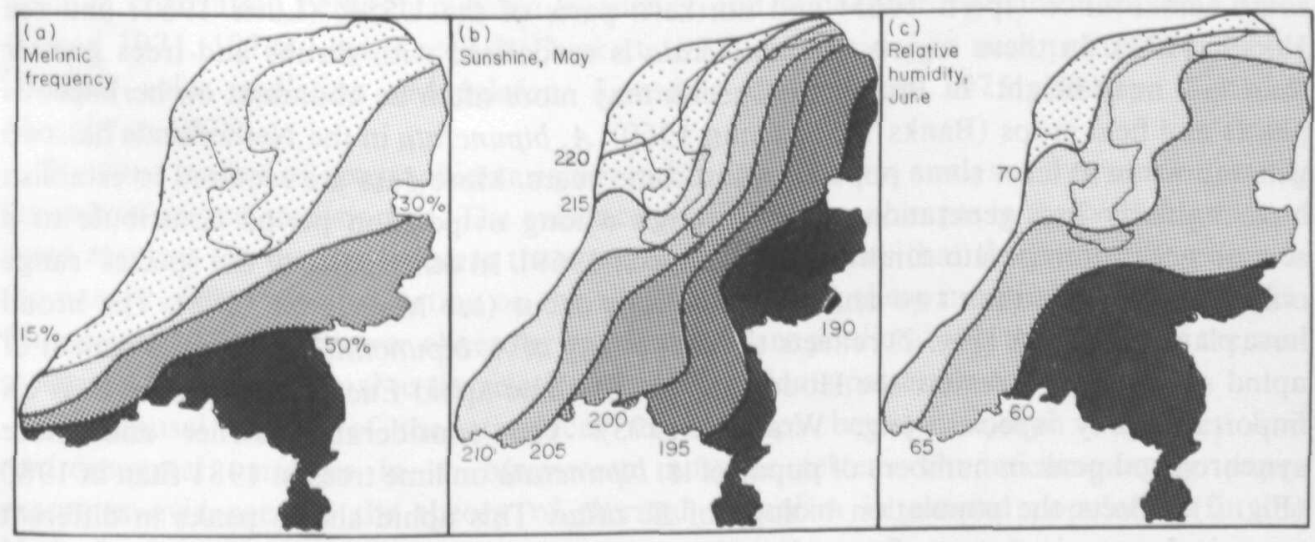

FIG. 7. Contour maps for melanic frequency in Adalia bipunctata and for hours of sunshine and $\%$ realtive humidity in the Netherlands.

TABLE 2. Numbers of non-melanics ( $\mathrm{n}-\mathrm{m})$ and of quadrimaculata (m4) and sexpustulata (m6) melanics in samples of adult Adalia bipunctata (data in Appendix 1) for each of six frequency classes. The proportions of melanics which are sexpustulata are given

$\begin{array}{crrrr}\begin{array}{c}\text { Frequency } \\ \text { class }\end{array} & \mathrm{n}-\mathrm{m} & \begin{array}{c}\text { Numbers* } \\ \mathrm{m} 4\end{array} & \mathrm{~m} 6 & \begin{array}{c}\text { \% frequency } \\ \mathrm{m} 6 \text { in melanics }\end{array} \\ 0-9 \cdot 9 & 7167 & 396 & 177 & 30 \cdot 89 \\ 10 \cdot 0-19 \cdot 9 & 3843 & 455 & 219 & 32 \cdot 49 \\ 20 \cdot 0-29 \cdot 9 & 11714 & 2492 & 1012 & 28 \cdot 88 \\ 30 \cdot 0-39 \cdot 9 & 838 & 307 & 126 & 29 \cdot 10 \\ 40 \cdot 0-49 \cdot 9 & 5189 & 3143 & 1011 & 24 \cdot 34 \\ 50 \cdot 0-59 \cdot 9 & 5229 & 4397 & 1471 & 25 \cdot 07 \\ \text { * Figures for }>60 \cdot 0 \% \text { melanics are 32, 39 and 16 respectively. }\end{array}$


June and particularly in winter (cf. climatic maps in K.N.M.I. 1972). The correlation between the average annual hours of sunshine (1951-1980) and melanic frequency for twenty-one study sites which can be matched to meteorological stations is -0.45 $(P<0.05)$. This is somewhat lower than, but in the same direction as, the corresponding correlations shown in Britain (Muggleton, Lonsdale \& Benham 1975). It is consistent with the theory of thermal melanism which predicts that melanic beetles are favoured in conditions of low sunshine because of a more efficient absorption of solar radiation (Lusis 1961; Benham, Lonsdale \& Muggleton 1974; Muggleton, Lonsdale \& Benham 1975; Brakefield \& Willmer 1984). There are, however, stronger relationships with other climatic variables in the study area. The negative correlation with relative humidity is illustrated in Fig. 7a and c. This relationship is also strongest in the months April-June. The correlation of average annual mean relative humidity and melanic frequency is -0.75 (d.f. $=12$, $P<0.01$ ). The highest value of -0.90 (d.f. $=12, P<0.001$ ) is found with the index of oceanity examined by Bengston \& Hagen (1977). These observations and the existence of significant correlations between climatic variables emphasizes the caution necessary in interpreting such data (see Bishop, Cook \& Muggleton 1975).

\section{DISCUSSION}

The sequence of breeding habitats for A. bipunctata in the study area is similar to those in south-east France (Iperti 1965) and northern parts of the USSR (Lusis 1961; and see Hodek 1973). In these regions $A$. bipunctata is associated with shrubs and trees greater than 1-2 $\mathrm{m}$ in height. In Britain the species may more often be abundant on herbaceous plants and field crops (Banks 1955; Dunn 1960). A. bipunctata in the Netherlands has two generations in at least some populations in some years. More data are required to establish how regularly first generation adults through a long oviposition period contribute to a second generation in late summer (see Ellingsen 1969). In other parts of the species' range only one, or more than two annual generations occur (see Muggleton 1978). The broad host plant utilization (Fig. 2) reflects the polyphagy of $A$. bipunctata and the movement of aphid species (for a review see Hodek 1973). The lime aphid Eucallipterus tiliae L. is an important prey species (e.g. Wratten 1973). The considerably earlier and more synchronized peak in numbers of pupae of $A$. bipunctata on lime trees in 1981 than in 1980 (Fig. 2) reflects the population biology of E. tiliae. This aphid shows peaks in different years in June or in August-September. The regulation of this variation is dependent on the number of fundatrices hatching from overwintered eggs and on spring temperatures (Dixon 1971).

The steepest parts of the clines in the Netherlands (Fig. 6) occur in areas where populations are restricted to villages and are rather small and where rural environments include few suitable breeding habitats. Changes in melanic frequency were considerably more gradual in regions with large urban sites. This is consistent with Endler's (1977) theoretical prediction that clines will become steepened or stepped in the vicinity of a partial barrier to gene flow. The steep changes occur to one side of a wide $(c .1 .75 \mathrm{~km})$ waterway and not across it (Figs. 1 \& 6). This may, however, represent no more of a barrier than a similar stretch of rural environment (see Brakefield 1984a). The greater width of the cline along transect $\mathrm{D}$, which is further inland (Figs 1 \& 6), probably reflects a more gradual change in selection coefficients. There are areas of this transect where a similar distribution of habitats occurs to those characterized by steep changes in transects $\mathrm{B}$ and $\mathrm{C}$. It is possible, however, that no such area is within the critical range of the point at 
which net genic selection changes over from favouring non-melanics to melanics (see Endler 1977).

The negative correlation between melanic frequency and length of sunshine in the Netherlands is similar to those found in Britain (Muggleton, Lonsdale \& Benham 1975; see also Creed 1975). Bengtson \& Hagen (1977) show a negative correlation with annual number of clear days in Norway (sunshine itself was not analysed). The stronger relationship in April-June in the Netherlands is consistent with an influence of thermal melanism since this period is that of peak mating and oviposition activity and is when adults most commonly occur on low growing shrubs exposed to direct solar radiation rather than shaded among trees. Muggleton, Lonsdale \& Benham (1975) found higher correlations in the early spring and autumn months when ambient temperatures are lower. The strongest relationship found by Bengtson \& Hagen (1977) was a positive one between melanic frequency and an index of oceanity (see also Lusis 1961; Hodek 1973). This contrasts with the negative correlation in the Netherlands although the range in the index falls below, and is only about one-tenth of that in Norway. It is possible that the significant rise in melanic frequency in the coastal strip of transect B (Fig. 6) is related to a local positive influence of maritime climate. Other workers have described correlations with temperature variables (e.g. Scali \& Creed 1975; Creed 1975). There are no mechanistic explanations of the relationships with climatic variables other than length of sunshine. The positive correlation between melanic frequency and atmospheric pollution in some areas (Creed 1971, 1974; Lees, Creed \& Duckett 1973) may be due to such pollution reducing incident solar radiation (Muggleton, Lonsdale \& Benham 1975; Bishop, Cook \& Muggleton 1978).

Previous studies of geographic variation in Europe have not analysed frequency data for the individual melanic morphs. The evidence that frequency changes in the Netherlands are more marked for quadrimaculata than sexpustulata suggests that there are differences in the nature of the selection acting on the alleles controlling these morphs (see Creed 1971; Muggleton 1978). Shallower clines for sexpustulata are predictable if the effects of thermal melanism are proportional to the relative extent of melanic pattern in the morphs.

The causal nature of the statistical relationships between morph frequency and environmental variables in $A$. bipunctata must be tested. The accompanying paper examines evidence for the theory of thermal melanism in natural populations in the Netherlands.

\section{REFERENCES}

Banks, C. J. (1955). An ecological study of coccinellidae (Col.) associated with Aphis fabae Scop. on Vicia faba. Bulletin of Entomological Research, 46, 561-587.

Bengtson, S.-A. \& Hagen, R. (1977). Melanism in the two-spot ladybird Adalia bipunctata in relation to climate in western Norway. Oikos, 28, 16-19.

Benham, B. R., Lonsdale, D. \& Muggleton, J. (1974). Is polymorphism in two-spot ladybird an example of non-industrial melanism? Nature (London), 249, 179-180.

Bishop, J. A., Cook, L. M. \& Muggleton, J. (1978). The response of two species of moths to industrialization in northwest England. I. Polymorphisms for melanism. Philosophical Transactions of The Royal Society of London, B, 281, 489-515.

Bishop, J. A., Cook, L. M., Muggleton, J. \& Seaward, M. R. D. (1975). Moths, lichens and air pollution along a transect from Manchester to North Wales. Journal of Applied Ecology, 12, 83-98.

Brakefield, P. M. (1984a). Ecological studies on the polymorphic ladybird Adalia bipunctata in The Netherlands. II. Population dynamics, differential timing of reproduction and thermal melanism. Journal of Animal Ecology, 53, 775-790.

Brakefield, P. M. (1984b). Selection along clines in the ladybird Adalia bipunctata in the Netherlands: A general mating advantage to melanics and its consequences. Heredity, 52, (in press). 
Brakefield, P. M. \& Willmer, P. G. (1984). The basis of thermal melanism in the ladybird Adalia bipunctata: Differences in reflectance and thermal properties between the morphs. Heredity, (in press).

Creed, E. R. (1971). Melanism in the two-spot ladybird, Adalia bipunctata, in Great Britain. Ecological Genetics and Evolution (Ed. by E. R. Creed), pp. 134-151. Blackwell Scientific Publications, Oxford.

Creed, E. R. (1974). Two spot ladybirds as indicators of intense local air pollution. Nature (London), 249, 390-392.

Creed, E. R. (1975). Melanism in the two spot ladybird: the nature and intensity of selection. Proceedings of The Royal Society of London, B, 190, 135-148.

Dixon, A. F. G. (1971). The role of intra-specific mechanisms and predation in relating the numbers of the lime aphid, Eucallipterus tiliae L. Oecologia(Berlin), 8, 179-193.

Dunn, J. A. (1960). The natural enemies of the lettuce root aphid, Pemphigus bursarius (L.). Bulletin of Entomological Research, 51, 271-278.

Ellingsen, I.-J. (1969). Fecundity, aphid consumption and survival of the aphid predator Adalia bipunctata L. (Col., Coccinellidae). Norsk Entomologisk Tidsskrift, 16,91-95.

Endler, J. A. (1977). Geographic variation, speciation and clines. Monographs in Population Biology, 10. Princeton University Press, New Jersey.

Hodek, I. (1973). Biology of Coccinellidae. Academia, Prague.

Iperti, G. (1965). Contribution à l'étude de la spécificité chez les principales coccinelles aphidiphages des Alpes-Maritimes et des Basses-Alpes. Entomophaga, 10, 159-178.

K.N.M.I. (1972). Klimaat Atlas van Nederland. Koninklijk Nederlands Meteorologisch Instituut, The Hague.

Lees, D. R., Creed, E. R. \& Duckett, J. G. (1973). Atmospheric pollution and industrial melanism. Heredity, 30, 227-232.

Lus, J. J. (1982). On the inheritance of colour and pattern in lady beetles Adalia bipunctata L. and Adalia decempunctata L. Izvestie Byuro Genetiki, Leningrad, 6, 89-163.

Lus, J. J. (1932). An analysis of the dominance phenomenon in the inheritance of the elytra and pronotum colour in Adalia bipunctata. Trudy Laboratorii Genetiki, Leningrad, 9, 135-162.

Lusis, J. J. (1961). On the biological meaning of colour polymorphism of lady-beetle Adalia bipunctata L. Latvijas Entomologs, 4, 3-29.

Muggleton, J. (1978). Selection against the melanic morphs of Adalia bipunctata (two-spot ladybird): a review and some new data. Heredity, 40, 269-280.

Muggleton, J., Lonsdale, D. \& Benham, B. R. (1975). Melanism in Adalia bipunctata L. (Col., Coccinellidae) and its relationship to atmospheric pollution. Journal of Applied Ecology, 12, 451-464.

Scali, V. \& Creed, E. R. (1975). The influence of climate on melanism in the two-spot ladybird, Adalia bipunctata, in central Italy. Transactions of The Royal entomological Society of London, 127, 163-169.

Wratten, S. D. (1973). The effectiveness of the coccinellid beetle, Adalia bipunctata (L.), as a predator of the lime aphid, Eucallipterus tiliae L. Journal of Animal Ecology, 42, 785-802.

(Received 3 May 1983) 


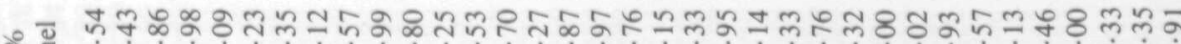

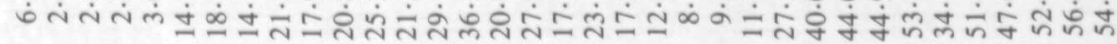

인


을


는


일

E



紊

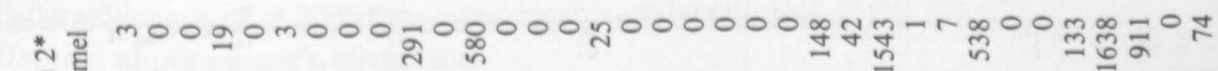
은 空

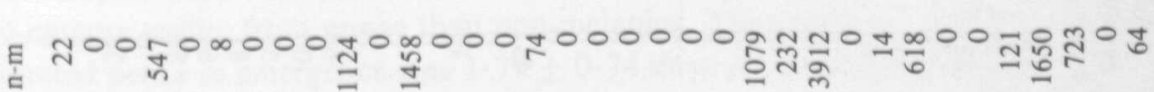
ํㅜㅇ



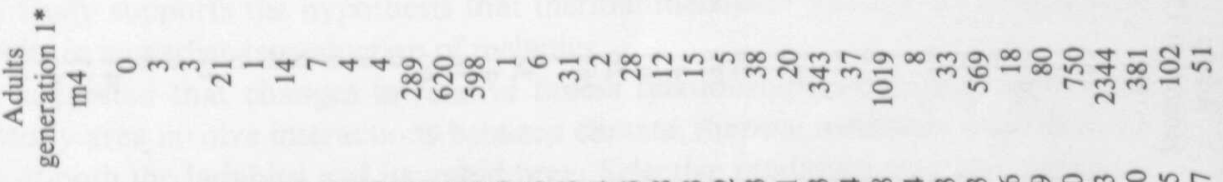

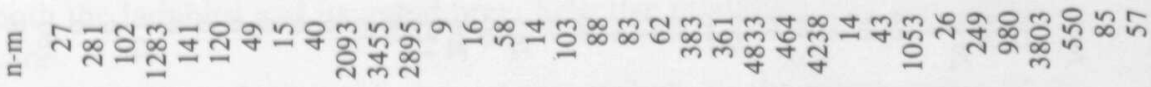


๑ ๙ ஸ̉ं

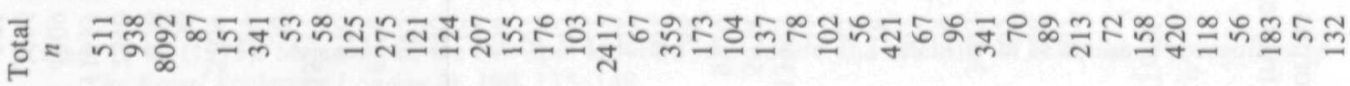
छ $0+\frac{6}{6} 000000000000 \frac{7}{2} 000000000000 m 000000000$

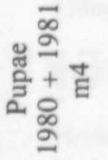

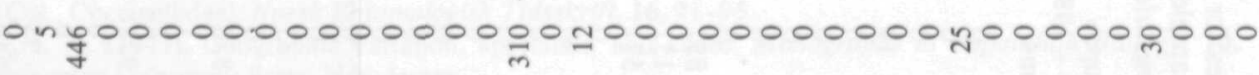
$\frac{1}{1} 0=\frac{1}{4} 0000000000000 \frac{h}{2} 000000000000000000000$

2.

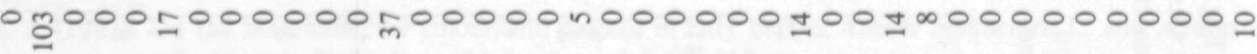
赵

$2 \infty$ $0 \infty 000$ m000000 $\frac{x}{2}$ * অ

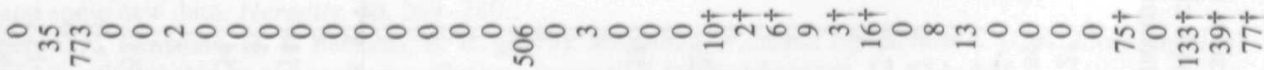

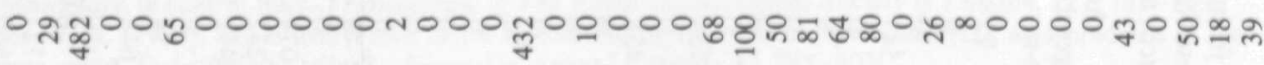
๕

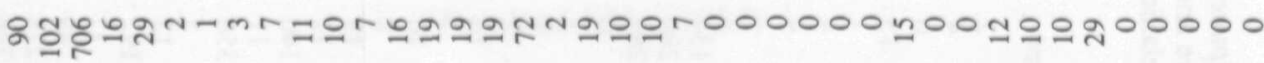
《密

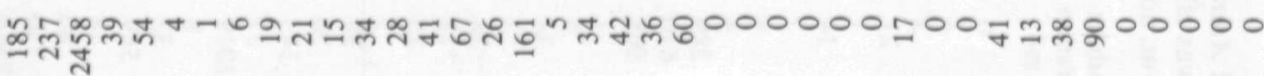

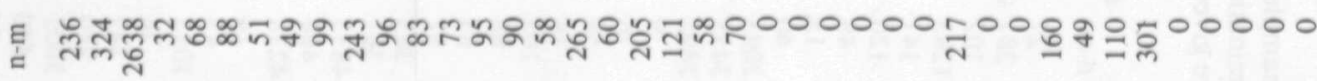

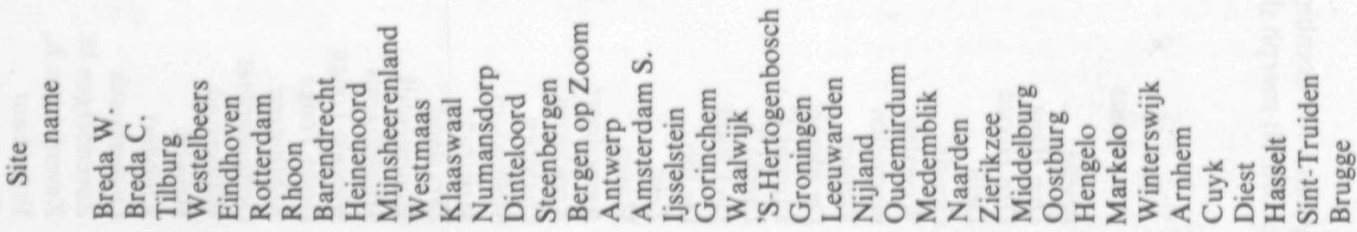

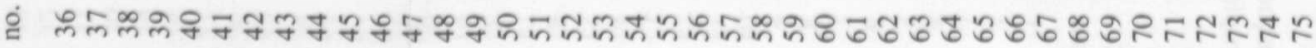

